\title{
Development of Learning Materials Based on Realistic Mathematics Education to Improve Problem Solving Ability and Student Learning Independence
}

\author{
Ainul Marhamah Hasibuan ${ }^{1 *}$, Sahat Saragih ${ }^{1}$, Zul Amry ${ }^{1}$ \\ ${ }^{1}$ State University of Medan, INDONESIA \\ *CORRESPONDENCE: $\square$ ainulmarhamahhsb@gmail.com
}

\begin{abstract}
The purpose of this study is to develop learning materials based on realistic mathematics education approach that are valid, practical and effective to improve problem solving skills and learning independence of class VII students. This research is a development research that uses a design model for materials development according to Thiagarajan, et al. namely 4-D. This trial was carried out in classes VII-3 and VII-4 Padangsidimpuan 5 Middle School. From the results of the study, it was found that developed devices were valid with an average total validity of RPP = 4.46 , student books $=4.41$, teacher's books $=4.38$, LAS $=4.31$; then a practical device can be implemented, with an average of $85 \%$ and $91.25 \%$. and effective devices, in terms of a) classical learning completeness of students in $62 \%$ I test increased in trial II has reached $92 \%$; and b) student responses to the components of positive learning. Based on the results of the study it was suggested that mathematics teachers can facilitate mathematical learning using quality learning materials and especially by using learning based realistic mathematics education approach.
\end{abstract}

Keywords: materials development, problem solving abilities, realistic mathematics education approach, student learning independence

\section{INTRODUCTION}

Education is an effort to advance the growth of character (inner strength, character), mind (intellect) and the growth of students to advance their lives in harmony with their world. In education given guidance by educators to the growth of students to show their lives (Daulay, 1998).

Education is also an inseparable thing from human life. Education can be used as a benchmark for the progress of the nation. An advanced nation is a nation that has quality human resources, both in terms of spiritual, intelligence and skills. One way that can be done to achieve this goal is continuous renewal in the field of education, especially mathematics.

Mathematics has a very important role in everyday life. Cornelius in (Mulyono, 2003) suggests that there are five reasons why mathematics needs to be studied, namely: "1) mathematics is a means of thinking clearly and logically, 2) a means of solving problems of daily life, 3) a means of recognizing patterns of relationships and generalizing experiences, 4) a means to develop creativity, and 5) a means to increase awareness of culture". This is in line with the general purpose of mathematics learning that is formulated National Council of Teacher Mathematics (2000) namely: (1) mathematical communication; (2) mathematical reasoning; (3) mathematical problem solving; (4) mathematical connection; (5) positive attitudes toward mathematics (Somakin, 2010). The description above shows that students 'mathematical abilities are very important factors for students' cognitive development and affect learning outcomes.

Article History: Received 21 September 2018 • Revised 30 November 2018 Accepted 14 December 2018

(C) 2019 by the authors; licensee Modestum Ltd., UK. Open Access terms of the Creative Commons Attribution 4.0 International License (http://creativecommons.org/licenses/by/4.0/) apply. The license permits unrestricted use, distribution, and reproduction in any medium, on the condition that users give exact credit to the original author(s) and the source, provide a link to the Creative Commons license, and indicate if they made any changes. 
Based on the results of research Dahlan (2012) the ability to think high consists of: the ability to think logically, critically, systematically, analytically, creatively, productively, reasoning, connection, communication, and problem solving. In line with the opinion of Saragih \& Napitupulu (2015) that: "The students are expected to use mathematics and mathematical mindset in daily life, and to study many kinds of sciences which stress to logical arrangement and student's character building and also ability to apply mathematics". In other words, students are expected to be able to achieve High Order Thinking Ability or Higher Order Thinking Skills (HOTS).

One of the high-level abilities examined by researchers is mathematical problem solving abilities. According to Rohmah and Sutiarso (2017) in his study that, problem solving is the interaction between knowledge and error that uses the process of applying cognitive and affective factors in problem solving. Surya and Rahayu (2017) juga also said in his research that problem solving is also a very important part of mathematics learning. This is because problem solving is a means to sharpen reasoning that is careful, logical, critical, analytical, and creative. Through mathematical problem solving, it allows students to become more analytical in making decisions in their lives. Problem solving ability is very important in everyday life, because we will never be free from problems. The importance of this problem solving ability is in line with the opinion of In'am (2014) that, Problem solving is a mental process that requires someone to think critically and creatively, to find alternative ideas and specific steps to overcome any obstacles or shortcomings. From the opinions above, it is only natural that the problem-solving ability must receive special attention, seeing its role as very strategic in developing students' intellectual potential.

But in reality students' problem solving abilities are still low. There is a study in Rohmah and Sutiarso (2017) that, Factors that cause errors when viewed from difficulties and student learning abilities are described as follows: 1) Students are not able to absorb information well, 2) Lack of Students' Experience in Working Hard, 3) Students do not understand the material carefully, 4) Weak Ability of the Concept of Prerequisites, 5) Student Negligence or Carelessness (in the process of work). In line with the initial research conducted by Saragih and Habeahan (2014) stating that in problem solving, it is often found that students only focus on the final answer without understanding how the answer process is correct or not. Frequent results show that the student's answer is wrong.

Besides the importance of mathematical problem solving abilities, another thing that is considered important is the attitude of students in learning mathematics, one of which is student learning independence. Independence of learning is related to independent learning but is not self-study or separating students from other students. As stated by Mu'tadin (2002), independent learning is not an attempt to alienate students from study partners. Students may ask questions, discuss or ask for explanations from others. Independence of learning will be formed from the independent learning process. In line with the study Pratama, et. al. (2017) that independence in learning is a necessity and need in education today. Fahradina, et. al. (2014) Revealing the main characteristics of self-study is the development of students' ability to carry out a learning process that does not depend on factors such as teachers, friends, class and others.

One important factor that can improve mathematical skills is to conduct quality learning by making the right learning materials. The use of learning materials provides good benefits in learning. The purpose of developing learning materials is to improve and produce new products. In addition, it aims to produce learning materials that are able to solve learning problems in the classroom, because basically there is no single source of learning that can meet all types of learning process needs. In other words the selection of learning materials, needs to be linked to the goals to be achieved in the learning process, especially in improving students' math skills, especially the ability to understand mathematical concepts and student self-learning.

Therefore, it is important for teachers to be able to develop learning materials to support the effectiveness and efficiency of learning, so that learning objectives can be achieved properly. Learning materials are said to be eligible if they meet valid, practical, and effective criteria.

Addressing the problems that exist in mathematics learning as described above, mainly related to mathematical problem solving abilities, student learning independence, approaches to learning and learning materials. Then it is necessary for the teacher or researcher to choose the model, approach, strategy and learning method. In line with the research of Laurens, et. al. (2017) that it is important for teachers to develop learning media, strategies, or learning models that are more appropriate, which are more in line with learning material or in the context faced by students. Furthermore, Zakaria and Muzakkir (2017) state that, the RME approach is the right method to improve the quality of the teaching and learning process. 
Table 1. Instruments and Data Analysis Techniques

\begin{tabular}{|c|c|c|c|}
\hline Aspects assessed & Instruments & Observed data & Respondents \\
\hline $\begin{array}{l}\text { Validation of PMR-based } \\
\text { learning materialss } \\
\text { Validation }\end{array}$ & Sheet & $\begin{array}{l}\text { Learning Implementation Plan, teacher } \\
\text { books, student books, LAS, Ability to solve } \\
\text { problems, and independence of learning }\end{array}$ & alist \\
\hline $\begin{array}{l}\text { PracticalPMR-based } \\
\text { learning materialss }\end{array}$ & $\begin{array}{l}\text { Observation } \\
\text { Sheet for the }\end{array}$ & Implementation ofLearning & Observer \\
\hline $\begin{array}{l}\text { Effectiveness of PMR-based } \\
\text { learning materialss }\end{array}$ & $\frac{\text { Tests }}{\text { Questions }}$ & $\begin{array}{l}\text { Tests Problem solving skills } \\
\text { StudentResponse }\end{array}$ & $\begin{array}{l}\text { Students } \\
\text { Students }\end{array}$ \\
\hline
\end{tabular}

Based on the description above related to the problems that lead to mathematical problem solving abilities and student learning independence is low. So researchers will conduct research to find solutions to existing problems by developing learning materials. This is what encourages researchers to conduct research with the title "Development of Based Learning materials Realistic Mathematics Approach to Improve Problem Solving Ability and Learning Independence of Padangsidimpuan 5 Middle School Students.

\section{METHODS}

This research is a development research. Development research is research that is used to develop or produce products or improve existing products (Sugiyono, 2009; Sukmadinata, 2005). This research is categorized into the type of Development Research (Development Research) using the model of the development of learning materials Thiagarajan, et al. (1974) namely 4-D models (define, design, develop, and disseminate).

The subjects in this study were VII-3 and VII-4 students of SMP Negeri 5 Padangsidimpuan 2017/2018 school year, and the objects in this study were learning materials through PMR, in this study to be developed is a quadrangular flat material mathematics learning materials in the form of Learning Implementation Plan, Teacher's Book, Student Book, Student Worksheet, test results of problem solving skills and Questionnaire for student learning independence.

Development of learning materials is said to be of quality if it fulfills three aspects which are valid, practical and effective. Learning materials have a good degree of validity if the minimum level of validity achieved is in the valid category. If the level of validity is below the valid category then revisions are made based on the input of the validators. Revisions are carried out so that valid learning materials are obtained. Activities carried out to analyze this data are:

a) Recapitulating the validity assessment data of learning materialss into a table which includes: aspects $\left(\mathrm{A}_{\mathrm{i}}\right)$, indicators $\left(\mathrm{I}_{\mathrm{i}}\right)$, and value $\mathrm{V}_{\mathrm{ji}}$ for each expert.

b) Determine the average value of experts for each indicator using the formula:

$$
I_{i}=\frac{\sum_{j=1}^{n} V_{j i}}{n}
$$

(Ja'far, et al., 2014)

description:

$\mathrm{V}_{j i}$ : Value data from theassessorj on theindicatori,

$n$ : Number of assessors (experts and practitioner)

c) Determine the average value for each aspect with the formula:

$$
A_{i}=\frac{\sum_{j=1}^{m} I_{i j}}{m}
$$

description:

$A_{i}$ : The mean values for aspects to $-i$,

$\mathrm{I}_{i j}$ : The average for aspectsto-iindicatort $0-j$,

$m:$ number of aspects indicator in $t o-i$

d) determining the values $V a$ or the total mean value of the mean values for all aspects with the formula:

$$
V a=\frac{\sum_{i=1}^{n} A_{i}}{n}
$$

(Ja'far et. al., 2014)

description: 
Table 2. Criteria for Validity Level

\begin{tabular}{ccc}
\hline No & $\boldsymbol{V a}$ or total mean value of & Validity Criteria \\
\hline 1 & $1 \leq V a<2$ & Invalid \\
\hline 2 & $2 \leq V a<3$ & Less valid \\
\hline 3 & $3 \leq V a<4$ & Sufficiently valid \\
\hline 4 & $4 \leq V a<5$ & Valid \\
\hline 5 & $V a=5$ & Very valid \\
\hline
\end{tabular}

Table 3. Assessment Criteria Keterlaksanaan Learning Activity

\begin{tabular}{ccc}
\hline Value & Interval Score & Criteria \\
\hline $\mathrm{A}$ & $k>90$ & Very Good \\
\hline $\mathrm{B}$ & $80<k \leq 90$ & Good \\
\hline $\mathrm{C}$ & $70<k \leq 80$ & Enough \\
\hline $\mathrm{D}$ & $60<k \leq 70$ & Less \\
\hline $\mathrm{E}$ & $k \leq 60$ & Very Less \\
\hline
\end{tabular}

Va: The mean total for all aspects of

$A_{i:}$ The mean values for aspectsto-i,

$n$ : number of aspects of the

Results are then written on the corresponding column in the table. Furthermore, the value $V a$ or total mean value referred to the interval for determining the validity level of learning materials based on the PMR approach, can be seen in Table 2.

The learning materials is said to be practical if the validator states that the developed Learning Tool can be used in a field with little revision or without revision. The results of the observation sheet during the learning process with the Learning Tool can show a positive increase in the implementation of learning. Data obtained from learning observation results are calculated as the percentage of implementation for each meeting, in the following way:

$$
\text { percentage }=\frac{\text { the number of checklists on the data }}{\text { the total number of learning stages }} \times 100 \%
$$

Next calculated the average percentage of the meeting as a whole. According Purnamasari (2014) As for the assessment criteria keterlaksanaan learning activities as presented in Table 3.

Products developed are said to be carried out if the average percentage of implementation of learning activities fulfills the minimum criteria of "Good".

Learning materials are categorized as effective if learning outcomes using learning materials show: 1) Students 'mastery learning is classically fulfilled, 2) students' responses to positive learning. Each student is said to have completed his study (individual provisions) if the proportion of answers is $75 \%$ correct and a class is said to be complete learning (classical provisions) if in that class there are $85 \%$ of students completing their studies (Trianto, 2011).

1) To determine student learning completeness (individual) used equation

$$
K B=\frac{T}{T_{t}} \times 100
$$

Description:

$K B \quad$ : Learning completeness

$T \quad$ : Number of scores obtained by students

$T_{t} \quad$ : Total score

Criteria:

$0 \% \mathrm{~B} \mathrm{PKB}<75 \%=$ students have not finished learning

$75 \% \mathrm{~B}$ PKB $<100 \%=$ students have completed learning

$\mathrm{PKB}=$ Percentage of Learning Completeness 
Table 4. Categories of Student Response in Learning Activities

\begin{tabular}{ccc}
\hline No & Percentage of student responses (\%) & Category \\
\hline 1. & $81-100$ & Sangat Positif \\
\hline 2. & $61-80$ & Positif \\
\hline 3. & $41-60$ & Cukup Positif \\
\hline 4. & $21-40$ & Tidak Positif \\
\hline 5. & $0-20$ & Sangat Tidak Positif \\
\hline
\end{tabular}

Table 5. Summary of Learning Materials Validation Results by Experts

\begin{tabular}{clcc}
\hline No & Object assessed & Average value of total validity & Level of Validation \\
\hline 1 & Books Student & 4,41 & Valid \\
\hline 2 & Books Teacher's & 4,38 & Valid \\
\hline 3 & Learning Implementation Plans & 4,46 & Valid \\
\hline 4 & Student Activity Sheet & 4,31 & Valid \\
\hline 5 & Test problem Solving ability & - & Valid \\
\hline 6 & Questionnaire learning Independence & - & Valid \\
\hline
\end{tabular}

Each student is said to have completed learning (individual completeness) if the final score of the student test is $75 \%$

2) To calculate learning completeness in a classical formula:

$$
P K K=\frac{\sum x_{i}}{n_{i}} \times 100 \%
$$

Description:

PKK : Percentage of classical completeness

$\sum x_{i}:$ Number of students who complete study

$n_{i} \quad$ : Number of all students

Classical learning completeness criteria are met if in the class there are $\geq 85 \%$ of students have completed learning

3) Determine the percentage of responses of students who respond according to criteria with the following formula:

Percentage of student response $=\frac{A}{B} \times 100 \%$ (Herman, 2012)

Description:

$A=$ the proportion of students who gave a positive response

$\mathrm{B}=$ the number of students who became respondents

Interpretation of the average questionnaire score in Table 4 using a modified Likert scale from (Riduwan. 2010).

At least $80 \%$ of many of the subjects studied gave a positive response to the materials that had been developed.

\section{RESULTS}

The results of the materials trial activities produce data on validity, practicality, and effectiveness. Validity data was obtained from two mathematics education lecturers who assessed the learning materials developed. The results of the validation of learning materials are shown in Table 5.

\section{Trial I}

The practicality of the materials is obtained from the results of the assessment of observation of the implementation of learning, assessment by the teacher. The practicality of the observation results of learning implementation is fulfilled if the implementation of learning reaches a good minimum category. The results of observations on the implementation of learning are presented in Table 6. 
Table 6. Results of Observation on the Implementation of Mathematics Based Learning PMR Trial I

\begin{tabular}{cc}
\hline Meeting & Percentage of Implementation Learning \\
\hline 1 & $80 \%$ \\
\hline 2 & $85 \%$ \\
\hline 3 & $85 \%$ \\
\hline 4 & $90 \%$ \\
\hline Average & $85 \%$ \\
\hline
\end{tabular}

Table 7. Level of Classical Completeness of Mathematical Problem Solving Ability in Trial I

\begin{tabular}{lcccc}
\hline \multirow{2}{*}{ Category } & \multicolumn{1}{c}{ Pretest } & \multirow{2}{*}{ Percentage } & Posttest & \multirow{2}{*}{ Percentage } \\
\cline { 2 - 2 } & Number of students & & Number of students & \\
\hline Completed & 13 & $50 \%$ & 16 & $62 \%$ \\
\hline Not Completed & 13 & $50 \%$ & 10 & $38 \%$ \\
\hline Total & 26 & $100 \%$ & 26 & $100 \%$ \\
\hline
\end{tabular}

Table 8. Results of Observation on the Implementation of Mathematics Based Learning PMR Trial II

\begin{tabular}{cc}
\hline Meeting & Percentage of Implementation Learning \\
\hline 1 & $85 \%$ \\
\hline 2 & $90 \%$ \\
\hline 3 & $95 \%$ \\
\hline 4 & $95 \%$ \\
\hline Average & $91,25 \%$ \\
\hline
\end{tabular}

Based on the data from the observation of the implementation of learning, it is known that the average percentage of learning implementation is $85 \%$. This means that the average implementation percentage lies in intervals of $80<\mathrm{k} \leq 90$. Thus, the implementation of learning using the realistic mathematics learning materials produced meets the Good category. This means that realistic mathematical learning materialss produced meet practical categories to be used in terms of observations of the implementation of learning analysis.

Analysis of the effectiveness of learning materials in terms of: (1) Classical learning completeness of students is $85 \%$ Students who take the test of problem solving ability have obtained a problem solving ability test score $\geq 75$; and (2) at least $80 \%$ of students respond positively to the learning materials developed. The effectiveness criteria of learning materials in terms of the problem solving ability test are based on the completeness of the posttest results. Pretest activities are still limited to knowing the condition of students' initial abilities before learning the material. Recapitulation of test completeness can be seen in Table 7 .

Based on the data in Table 7, it can be seen that students 'mastery learning in a classical manner from the results of students' mathematical problem solving abilities in the one pretest trial was $50 \%$ and posttest was $62 \%$. In accordance with the completeness criteria of student learning outcomes in a classical manner, that is, at least $85 \%$ of students who take the test of mathematical problem-solving ability can achieve a score of $\geq 75$. Thus, the posttest results of mathematical problem solving abilities have not fulfilled classical completeness. So it can be concluded that in the first trial the application of realistic mathematics-based learning materials developed did not meet the classical achievement criteria for completeness, then trial II will be conducted.

For effectiveness in terms of student responses to the learning materials developed, it is said to be effective if at least $80 \%$ of students give a positive response. The average percentage of the total positive responses of students in the first trial was $89 \%$. If the results of this analysis are referred to the criteria set, it can be concluded that students' responses to the components and learning activities are very positive. Because, more than $80 \%$ of students give a positive response to the components of the learning materials developed.

\section{Trial II}

The practicality of the device is obtained from the results of the assessment of observation of the implementation of learning, assessment by the teacher. The practicality of the observation results of learning implementation is fulfilled if the implementation of learning reaches a good minimum category. The results of observations on the implementation of learning are presented in Table 8. 
Table 9. Level of Classical Completeness of Mathematical Problem Solving Ability in Trial II

\begin{tabular}{lcccc}
\hline \multirow{2}{*}{ Category } & \multicolumn{2}{c}{ Pretest } & \multirow{2}{*}{ Percentage } & \multicolumn{2}{c}{ Posttest } & \multirow{2}{*}{ Percentage } \\
\cline { 2 - 2 } Number of students & Number of students & \\
\hline Completed & 20 & $77 \%$ & 24 & $92 \%$ \\
\hline Not Completed & 6 & $23 \%$ & 2 & $8 \%$ \\
\hline Total & 26 & $100 \%$ & 26 & $100 \%$ \\
\hline
\end{tabular}

Based on the data from the observation of the implementation of learning, it is known that the average percentage of learning implementation is $91.25 \%$. This means that the average implementation percentage lies in the interval $k>90$. Thus, the implementation of learning using the realistic mathematical learning tools produced meets the Very Good category. This means that realistic mathematical learning devices produced meet practical categories to be used in terms of observations of the implementation of learning analysis.

Furthermore, the analysis of the effectiveness of the learning device is viewed from: (1) Classical learning completeness of students, namely $85 \%$ Students who take the problem-solving ability test have obtained the problem-solving ability test score $\geq 75$; and (2) at least $80 \%$ of students respond positively to the learning devices developed. The effectiveness criteria of learning devices in terms of the problem solving ability test are based on the completeness of the posttest results. Pretest activities are still limited to knowing the condition of students' initial abilities before learning the material. Recapitulation of test completeness can be seen in Table 9.

Based on the data in Table 9, it can be seen that student learning completeness in a classical manner results from students' mathematical problem solving abilities on Trial II pretest was 77\% and postest was $92 \%$. In accordance with the completeness criteria of student learning outcomes in a classical manner, that is, at least $85 \%$ of students who take the test of mathematical problem-solving ability can achieve a score of $\geq 75$. Thus, the posttest results of mathematical problem solving abilities have met the completeness classically. So it can be concluded that in the first trial the application of realistic mathematics-based learning devices developed had not met the criteria for achieving classical completeness.

For effectiveness in terms of student responses to the learning device developed, it is said to be effective if at least $80 \%$ of students give a positive response. The average percentage of the total positive responses of students in trial II was $90 \%$. If the results of this analysis are referred to the criteria set, it can be concluded that students' responses to the components and learning activities are very positive. Because, more than $80 \%$ of students give a positive response to the components of the learning device developed.

\section{DISCUSSION}

From the description above, there are quality learning devices, namely devices that have been developed and meet valid, practical and effective criteria. Learning devices that fulfill good valid aspects according to Rahman and Amri (2013) are, that the aspect of validity refers to the extent to which the design of the devices developed is based on content validity and construct validity. Akbar (2013) added that high validity was obtained through validation testing of the learning devices developed. From the opinion of experts, it is also supported by research carried out by Sahara (2017) where, Based on expert team validation and revisions made, it was found that the development of learning tools carried out on teacher books, student books, lesson plans, worksheets and tests that the results of device validation are in the validity criteria with the category "very valid" and can be applied. In line with Ja'far, et. al., (2014) where, the learning tools produced in this study include the Learning Implementation Plan (RPP), student books, and Student Worksheets (LKS) that are character-based consistent and meticulous using the RME approach. Based on the results of validation and field trials the learning devices developed have met valid criteria.

Learning tools that have been developed meet the practical aspects of good or easy categories of implementation. Practicality is that learning devices are prepared taking into account convenience. Ease in the sense that compiled learning devices can be easily understood and also easy to implement or use (Nieveen, 1999). According to Arikunto (2012), it means that practicality in educational evaluation is the facilities available in evaluation instruments both in preparing, using, interpreting / obtaining results, and in saving. This is supported by the research results of Riskasusanti, et. al., (2017) which show that the development of realistic learning tools developed with the 4-D model produces good learning tools, namely practicality and improving students' problem solving abilities and dispositions. According to the study of Ammamiarihta, et. 
al., (2017) that "Learning devices have met the practical criteria in terms of the validator. In addition, research conducted by Purwanti (2017) states, that the results of the trials have met the practical criteria with categories. "Very easy to implement". The data is supported by observational data on the implementation of mathematics learning with the PBM model, with an average percentage of implementation reaching $91.67 \%$.

Learning tools that have been developed meet the effective aspects in terms of clarity of learning classically and positive student responses. Based on the results of the analysis of trials I and II, it was found that the mathematical problem solving abilities of students had met the classical completeness criteria. This is because, the material and problems that exist in the student book and activity sheet are developed, according to the conditions of the student learning environment and refer to PMR-based learning. With the application of PMR-based learning devices, students will be actively involved in the problem solving process. Students analyze and evaluate their own thought processes and draw conclusions from knowledge found with guidance and guidance from the teacher or friend in the form of questions that lead. This is reinforced by Vygotsky (Rusman, 2012) namely, learning based on problems is an effort to associate new information with cognitive structures that have been owned through learning activities in social interaction. Vygotsky (Arends, 2008b) adds social interaction with other people both teachers and peers referring to constructing new ideas and increasing students' intellectual development. This is supported by the results of the study of Fauzan and Yerizon (2013), namely learning by using PMR can improve student mastery learning in learning, especially mathematical abilities and student learning independence.

Learning tools through realistic mathematical approaches can arouse student interest in learning so that learning activities become effective. According to Vigotsky's theory (in Trianto, 2011), namely: (1) the nearest development area; i.e. learning occurs when a child works or learns to handle tasks that have not been studied but the tasks are still in their abilities or those tasks are in the zone of poximal development; and (2) scaffolding, namely giving a large amount of assistance to a child during the initial stages of learning, then the child takes on the responsibility that gets bigger as soon as he can do it himself. Positive responses given by students are caused because the teacher has provided a stimulus in the form of feedback and reinforcement that is in accordance with the characteristics of students after studying the classroom conditions. In line with the opinion of Subandi (1982) that the response in terms of feedback (feedback) has a response or a large influence in determining whether or not a communication. In other words the teacher is a component that determines the implementation of a learning strategy.

This statement is in line with Sanjaya (2010), namely the learning process is a complex process, which must take into account the various possibilities that will occur, those possibilities which then require careful planning from each teacher. A teacher must prepare a mature and accurate learning process because with learning planning the teacher will predict how much success will be achieved. This is reinforced by the results of a study by Maulydia, et al., (2017) "Students respond to teaching material that has been developed through RME is positive because it is more than $80 \%$ of students are taught to teach the teaching process by teaching material that has been developed." In line with the results of the study Pratama, et al. (2017) stated: "Students give a positive response to learning by using PR-TKBMD. The student response given in trial This indicates that learning using PR-TKBMD has met the effective criteria in terms of student response. Student response given in trial II has a high category that is $92.87 \%$ It shows that learning by using PR-TKBMD has a fulfilled effective criterion in terms of student response."

\section{CONCLUSION}

From the discussion above, it can be concluded that mathematical problem solving abilities and student learning independence increase after learning using learning tools based on realistic mathematical approaches that have been developed. This study shows that the quality of learning tools must have valid, practical and effective criteria.

\section{Disclosure statement}

No potential conflict of interest was reported by the authors. 


\section{Notes on contributors}

Ainul Marhamah Hasibuan - Post Graduate Mathematics Education Program, Universitas Negeri Medan, Medan, Indonesia.

Sahat Saragih - Doctor of Mathematics Education, Acessor, Associate Professor, Master of Science, Lecturer, Mathematics Department Universitas Negeri Medan, Medan, Indonesia.

Zul Amry - Doctor of Mathematics Education, Master of Science, Lecturer, Mathematics Department, Universitas Negeri Medan, Medan, Indonesia.

\section{REFERENCES}

Akbar, S. (2013). Learning Instrument. Bandung: Remaja Rosdakarya.

Ammamiarihta., Syahputra, E., \& Surya, E. (2017). Development of Learning Devices Oriented Problem Based Learning to Increase Student's Combinatorial Thinking in Mathematical Problem Solving Ability. Annual International Seminar on Transformative Education and Educational Leadership (AISTEEL 2017), 104, 334-339. https://doi.org/10.2991/aisteel-17.2017.71

Arends, R. I. (2008b). Learning to Teach, Belajar untuk Mengajar. Edisi Ketujuh. Jidil Dua. (diterjemahkan oleh Soedjipto, Helly, P. dan Soedjipto, Sri, M.) Yogyakarta: Pusataka Pelajar.

Arikunto. (2012). Basics of Educational Evaluation. Jakarta: Bumi Aksara.

Dahlan, J. A. (2012). Implementation of Cognitive Conflict Learning Strategies in Improving Efforts High Order Mathematical Thinking Siswa. Journal of Education, 13(2), 65-76.

Daulay, A. S. (1998). Educational Sciences. Medan: CV Jabal Rahmat.

Fahradina. N., Ansari, B I., \& Saiman. (2014). Mathematical Communication Capability Enhancement and Learning Independence of Middle School Students Using Group Investigation Models. Mathematics Didakti Journal, 1(1), 54-64.

Fauzan, A., \& Yerizon. (2013). The Effect of the RME Approach and Learning Independence on Students' Mathematical Ability. Prosiding Semirata FMIPA Universitas Lampung, 7-14.

Herman. (2012). Development of Learning Devices Direct Teaching Models to Teach Equivalent Material to Equivalent Objects. Journal of Physics and Education, 8(1), 1-11.

In'am, A. (2014). The Implementation of the Polya Method in Solving Euclidean Geometry Problems. Internasional Education Studies, 7(7), 149-158. https://doi.org/10.5539/ies.v7n7p149

Ja'far, M., Sunardi, \& Indah, A. K. (2014). Development of Consistent and Thorough Character Based Learning Devices Using Realistic Mathematics Education (RME) Approach in the Chapter of Constructivity and Kekongruenan Build Flat Class IX SMP. Jurnal Edukasi UNEJ. I(3), 29-35.

Laurens, T., Adolfina, F. B., Rafafy, J. B., \& Leasa, M. (2017). How Does Realistic Mathematics Education (RME) Improve Students' Mathematics Cognitive Achievement? EURASIA Journal of Mathematics, Science and Technology Education, 14(2), 569-578.

Maulydia, S. S., Surya, E., \& Syahputra, E. 2017. The Development of Mathematic Teaching Material Through Realistic Mathematics education to Increase Mathematical Problem solving of Junior High School Students. International Journal of Advance Research and Innovative Ideas in Education (IJARIIE). 3(2), 2965-2971.

Mu'tadin, Z. (2002). Independence as Adolescent Psychological Needs. Retrieved from http://www.epsikologi.com/remaja.050602

Mulyono, A. (2003). Education for Children with Learning Difficulties. Jakarta: Rineka Cipta.

Nieveen, N. (1999). Prototyping to Reach Product Quality. In Jan Van den Akker, R.M. Branch, K. Gustafson, N. Nieveen \& Tj. Plomp (Eds). Design Approaches and Tools in Education and Training (pp 125-135). Nederlands: Kluwer Academic Publishers.

Pratama, S., Minarni, A., \& Saragih, S. (2017). Development of Learning Materialss Based on Realistic Approach Integrated Context Malay Deli Culture To Improve Ability of Understand Mathematical Concepts and Students' Self-Regulated Learning At SMP Negeri 5 Medan. Journal of Mathematics (IOSR-JM), 13(6), 18-29. 
Purnamasari, Y. (2014). The Influence of the Cooperative Type TGT Learning Model on Learning Independence and Increasing the Reasoning and Mathematical Ability of Students of Tasikmalaya 1 Junior High School. Journal of Education and Teacher Training, 1(1), 1-11.

Purwanti, D. (2017). Development of Learning Tools Oriented Problem-Based Learning to Improve Problem Solving Capabilities and Student Learning Independence of SMA 1 Kualuh Selatan High School (Unpublished thesis). Medan: Post Graduate Program UNIMED.

Rahman \& Amri. (2013). Strategy and Design of Learning System Development. Jakarta: Prestasi Pustaka.

Riduwan. (2010). Easy Learning Research for Teachers-Employees and Beginner Researchers. Bandung: Alfabeta.

Riskasusanti, D., Fauzi, KMS. M. A., \& Simbolon, N. (2017). Development of Materials to Improve the Ability of Resolution and Disposition Mathematic Through Mathematical Approach Realistic in Class V SD Negeri Lamsayeun Aceh Besar. Journal of Education and Practice, 8(24), 42-51.

Rohmah, M., \& Sutiarso, S. (2017). Analysis Problem Solving in Mathematical Using Theory Newman. EURASIA Journal of Mathematics, Science and Technology Education, 14(2), 671-681. https://doi.org/10.12973/ejmste/80630

Rusman. (2012). Learning Models: Developing Teacher Professionalism. Jakarta: Rajawali Pers.

Sanjaya, W. (2009). Learning Strategies Oriented to Educational Process Standards. Jakarta: Kencana.

Saragih, S., \& Habeahan, W. (2014). The Improving of Probem Solving Ability and Students' Creativity Mathematical by Using Problem Based Learning in SMP Negeri 2 Siantar. Journal of Education and Practice, 5(35), 123-132.

Saragih, S., \& Napitupulu, E. (2015). Developing Student-Centered Learning Model to Improve High Order Mathematical Thinking Ability. International Education Studies, 8(6), 104-112. https://doi.org/10.5539/ies.v8n6p104

Sarah, N. (2017). Development of Learning Devices Based on Realistic Mathematical Approaches to Enhance Mathematical Representation Capabilities and Self Efficacy of Students. Journal MIPA Education Research, 2(1), 104-115.

Somakin. (2010). Developing Student Self-efficacy through Mathematics Learning. Sriwijaya (Online) Paradikma Journa, 3(1).

Subandi, A. (1982). Social Psychology. Jakarta: Bulan Bintang.

Sugiyono. (2009). Educational Research Methods: Qualitative, Quantitative, and R\&D. Bandung: Alfabeta.

Sukmadinata, N. S. (2005). Educational Research Methods. Jakarta: PPS UI dan Remaja Rosdakarya.

Surya, E., \& Rahayu, R. 2017. Improving Communication Ability and Solving Mathematical Problems of ARRahman Percut Middle School Students through STAD Type Cooperative Learning. Journal of Mathematics Education PARADIKMA, 7(1), 24-34.

Thiagarajan, S. Semmel, D. S., \& Semmel, M. I. (1974). Instructional Development for Training Teachers of Exceptional Children: A sourcebook. Indiana: Indiana University.

Trianto. (2011). Mendesain Model Pembelajaran Inovatif Progresif. Konsep, Landasan, dan Implementasinya pada KTSP. Jakarta: Kencana Prenada Media Group

Zakaria, E., \& Muzakkir, S. (2017). The Effect of Realistic Mathematics Education Approach on Students' Achievement and Attitudes towards Mathematics. Journal Mathematics Education Trends and Research, 2017(1), 32-40. https://oi.org/10.5899/2017/metr-00093 